\title{
Confronting Apprenticeships of Observation: How Student-Faculty Pedagogical Partnership Complicates Conceptualization, Understanding, and Practice of Effective Pedagogy
}

\begin{abstract}
*Jerusha Conner Department of Education and Counseling, Villanova University, Villanova, PA, USA
\end{abstract}

Contact: jerusha.conner@villanova.edu

Gwendolyn Vary, Department of History, Bryn Mawr College, Bryn Mawr, PA, USA

\section{INTRODUCTION}

In 1975, Dan Lortie introduced the term "the apprenticeship of observation" to refer to the years students spend watching their teachers teach them and the ways in which these observations inform their views of what constitutes good teaching. The apprenticeship of observation poses three challenges for aspiring and practicing educators. First, the ideas they form about effective teaching are based on only one learner's preferences, needs, and experiences: their own. Therefore, they may not have a broad understanding of what works for students whose learner profiles (i.e., strengths, weaknesses, and learning styles) differ from their own. They may favor teaching in the way they would like to be taught, rather than in the ways that their students need. Second, their repertoires of practice are limited to that which they have seen. Without first-hand experiences with alternative teaching approaches, they may lack the knowledge and the will to move beyond the models they have experienced. Third, the apprenticeship of observation gives students only a partial view of the work of teaching. They do not see the behind-the-scenes deliberations that go into choosing curricular materials, developing a lesson plan, and assessing students. Differentiation techniques, in which teachers engage students in different activities or assignments based on students' unique interests, learner preferences, or needs, are obscured in the apprenticeship of observation.

Although teacher-education programs present an ideal space and time for aspiring $\mathrm{K}-12$ teachers to confront and overcome their apprenticeships of observation, few higher education professors have comparable opportunities to recognize the influence of their apprenticeship of observation on their instructional approach, to interrogate it, and ultimately to move beyond the limits it has imposed on their conceptualization, understanding, and practice of effective pedagogy. In recent years, student-faculty partnerships have emerged in higher education as a means of supporting instructors in reflecting on, analyzing, and, in some cases, changing their teaching practice (Cook-Sather \& Abbot, 2016). 
In this essay, we consider how student-faculty partnerships create opportunities for both college students and professors to confront their apprenticeships of observation, and we explore the challenges and benefits of doing so with one another. We begin with a short description of the context of our partnership, the Students as Learners and Teachers (SaLT) program at Bryn Mawr and Haverford Colleges, and then detail our experiences as a student and a professor in such a partnership. We draw on examples from our recent work together to show what our partnership looked like in practice and to illuminate the insights, inspirations, and ongoing questions this collaboration has generated for us about our apprenticeships of observation.

\section{THE CONTEXT OF OUR PARTNERSHIP: THE STUDENTS AS LEARNERS AND TEACHERS PROGRAM}

Based at Bryn Mawr and Haverford Colleges since 2006, the SaLT program takes the form of semester- or year-long one-on-one partnerships between faculty members and undergraduate students who are not currently enrolled in the course upon which the faculty member focuses for the partnership. The student partner takes a range of approaches to observing, analyzing, and engaging in constructive dialogue with the faculty partner (CookSather \& Motz-Storey, 2016). This reflection essay explores the student-faculty partnership between its two co-authors: Gwendolyn, an undergraduate at Bryn Mawr, and Jerusha, an Education Professor at Villanova. In the spring of 2016, we undertook a pedagogical partnership, the second partnership Jerusha had undertaken through the SaLT program (Conner, 2012). This partnership focused on a graduate education course Jerusha was teaching.

Nearly every week throughout the semester, Gwendolyn attended Jerusha's class and took detailed notes, which contained her observations on teaching methods and interactions, as well as on any particular issue Jerusha had asked her to attend to. We also met before and after each class to review the lesson plan and its implementation. Gwendolyn offered advice on a specific section of the lesson or on how to engage and support a particular student, drawing on conversations she had had with her fellow student partners and with the director of the SaLT program, Professor Alison Cook-Sather, at Bryn Mawr College. During these meetings Gwendolyn shared what she had noticed and heard, what she thought had worked and didn't work as intended, and any suggestions she had for new approaches moving forward.

Together, Jerusha and Gwendolyn made sense of unexpected or puzzling moments in class, such as when students did not engage with the material in an intended way or particularly struggled with an activity. We also analyzed spur-of-the-moment decisions Jerusha had made to deviate from the lesson plan. In addition, we looked ahead to the subsequent week, anticipating upcoming learning objectives for the students in the course as well as areas of teaching that Jerusha might like to try to improve. Gwendolyn also served as a resource for the students to improve their learning experience. For example, she assisted in obtaining midsemester feedback from the students, and she offered them the opportunity to come forward with problems or challenges they were not comfortable discussing with Jerusha.

In what follows, we detail the insights, new practices, and ongoing questions our partnership yielded. Using the lens of the apprenticeship of observation, we focus on the concept of listening.

2 Conner, J. \& Vary, G. Confronting Apprenticeships of Observation: How Student-Faculty Pedagogical Partnership Complicates Conceptualization, Understanding, and Practice of Effective Pedagogy International Journal for Students as Partners 1 (1) 


\section{JERUSHA'S INSIGHTS INTO LISTENING}

Our relationship began with a simple question. Gwendolyn sat in a chair in my office and asked me, "How do you like to be listened to?" The question surprised me. I had never considered this matter before, and I told her that I didn't know that I had a preference, though I do appreciate eye contact. She then volunteered that she did not like it when people interrupted her or spoke over her. As I chuckled and responded, "Who does?," she shot me a look. I had just spoken over her! She was not done with her thought, but I had interjected. I had done exactly what she was trying to ask me not to do.

As we continued to try to get to know one another, to review the syllabus and my goals for students in the course, I found myself becoming painfully self-aware of my tendency to want to finish her sentences, especially when she seemed to be searching to find the right word. I wanted to convey that I heard, understood, could relate, and could help, but she was cautioning me that she would not interpret my overtures in the way that I intended them. My efforts to establish rapport might instead be seen as efforts to exercise my authority and to minimize her agency. I was humbled knowing I would have to find other ways to signal to her that I was listening and that I understood.

Although she had held up a mirror for me in our very first conversation, it wasn't until our first debriefing session after class that she helped me to recognize that this "over-speaking" tendency of mine spilled over from the one-on-one setting of my office to my classroom. Reviewing her notes from her first observation of the class, Gwendolyn asked me if I realized that I hummed while students were speaking. I was stunned. I hum? How distracting and disrespectful! As Gwendolyn clarified and illustrated, I recognized what I would call my proclivity to respond to students' comments with non-verbal vocal expressions that signal agreement ("mm-hmm!"), interest ("uhhmm!"), or uncertainty (“hmmm?"). As I reflected on this tendency, at first defensively, I realized that I had reasons for doing it. Sometimes, I wanted to help someone who was rambling to wrap up. In those cases, I was offering a non-verbal punctuation mark. In other cases, I was trying to underline or highlight what I saw as a valuable or insightful comment for the other students. I believed these noises, accompanied by my facial expressions, smiles, raised eyebrows, head nods or tilts, would communicate my desire to move on from, affirm, punctuate, or question a student's comments. But that Gwendolyn heard these vocalizations of mine as humming troubled me. While I knew why I was doing them, I didn't know how they were being heard or received by my students. Perhaps my students heard them as irritants too.

As I write this, I wonder now why I didn't simply turn Gwendolyn's question to them. "How do you like to be listened to?" Instead, I shared with them that Gwendolyn had helped me see this tendency of mine and that I was working on it, but I never asked them how they thought I was doing on those accounts or whether it was something they wanted me to change. During class discussions, I became acutely self-aware, knowing that Gwendolyn would be listening for my humming. I fought hard to curb this well-worn tendency; I sometimes caught myself slipping in a "hmmmm" and felt an immediate sense of shame. At points, I wondered if I was paying more attention to myself and how I responded than I was to the students' actual comments. At the same time, this struggle forced me to think more deeply about why it is that I 
feel the need to use these cues to signal to students that I am in control of the conversation, even when I am not speaking.

Throughout the semester, as I struggled with these questions, I learned that I want to be listened to in the way that I tend to listen to my students. I want to hear affirmations and incredulity, to see head nods and head tilts, a cocked eyebrow or furrowed brows; and I interpret these expressions as signs of engagement. I don't mind when people finish my sentences (especially if they do so with the words I would choose, or even better words). Gwendolyn taught me that I have unwittingly, unintentionally imposed my preferences on my students. Even though I am well aware of the apprenticeship of observation, I had never been challenged to confront or address this verbal listening tendency of mine until I met with Gwendolyn, and even when she called it to my attention, I found it very hard to unwind.

\section{GWENDOLYN'S INSIGHTS INTO LISTENING}

Over the semester that I worked with Jerusha, I would additionally meet weekly with other students working as partners in the SaLT program and the program's director Alison Cook-Sather. At these meetings, we would exchange experiences that went well in our various placements, as well as concerns that had come up. These meetings were essential to processing my own experience and to my ability to give Jerusha helpful feedback. The students in these meetings had a wide variety of experiences as learners, generating a broad range of strategies and ideas to be shared with the group. I listened to what other students shared, always with an ear to what I could share with Jerusha. This kind of listening pushed me to consider options for engaging Jerusha's students that I might not have thought of or considered based only on my own experiences and preferences as a learner.

One particular phenomenon in Jerusha's classroom that I noted was that she would often run out of time and be forced to end class with open questions for them to think about as they made their ways drove home. Through collaborative discussion in my student-partners meetings I discovered a solution that could enable Jerusha to be more productive at the end of her class: exit tickets. I viewed this tool as a vehicle for her to listen to her students and for her students to listen to themselves about their learning, rather than have their voice and thoughts trail off at the end of class.

The student partners I met with discussed how they had appreciated the exit ticket activity as a chance to reflect, as well as the chance to engage with any material that they might have not gotten the chance to talk about in class. An exit ticket is a low-stakes activity at the end of class that a student can do in just a few minutes. This can take many forms including a one-minute mini-essay or a three-question quiz. This activity also holds students accountable for doing the readings and learning from class activities and allows them to ask questions or share reflections that they might not have offered during class. This exercise is enhanced by picking specific questions that the student will be able to write down quickly and that the teacher can look over and follow up on later with a student if necessary.

In creating a specific exit ticket that would work for this class, Jerusha and I first decided to invite students to write down one thing that that they said, one thing that someone else had said, and one thing they wish they had said. We hoped this exit ticket might prompt the students to recognize the imbalance between the different students' voices in the classroom

4 Conner, J. \& Vary, G. Confronting Apprenticeships of Observation: How Student-Faculty Pedagogical Partnership Complicates Conceptualization, Understanding, and Practice of Effective Pedagogy International Journal for Students as Partners 1 (1) 
that we had noticed ourselves, as they reflected on not only how they were contributing to the conversation but how other students were contributing to the conversation as well. This would, in turn, lead them to reflect on the conversation happening in the classroom in a new way.

We also tried a three-Ws exit ticket (this exit ticket asks students to complete the following statements: One thing I wonder after class tonight is..., one thing I wish I had done or said differently in class tonight is..., and one thing I want to try to do in this class moving forward is ...) and an exit ticket that asked students to write down three words that for them captured the substance of the class that evening and then to share them in a whip-around, which quickly moves from one student to the next. This whip-around was followed by a short debrief on some of the most commonly chosen words as well as outliers and their significance. Even now, Jerusha continues to use variations of the exit ticket in her classes to encourage students' metacognitive reflection and create opportunities for listening at the end class.

\section{OUR ONGOING QUESTIONS ABOUT TEACHING AND LEARNING}

Although our formal partnership is concluded, the ways in which we each helped the other to challenge our apprenticeships of observation and the particular effect of those apprenticeships on our assumptions about and practices of listening continue in the form of questions both of us are taking forward.

Jerusha: Among the many things our partnership yielded, including greater selfawareness, new pedagogical techniques, and a strong friendship based on mutual respect and reciprocal learning, were several lingering questions. For me, these questions concern issues of authenticity and perspective. I have given more thought to whether it is desirable (or even possible) for a teacher to adjust her natural style or personality in the classroom to suit students' needs or preferences. When, if ever, should we repress our natural tendencies as teachers because they may be off-putting to students? While we all know we cannot force ourselves to be something we aren't in the classroom (for example, even if I wanted to be more funny in the classroom, clever witticisms and jokes are not things that come easily), is it equally problematic to repress something we are? I also wonder whether differentiated listening in whole class discussion contexts is possible or desirable. Would splitting the difference between mine and Gwendolyn's listening preferences result in a listening pedagogy that has all the faults and none of the advantages of a method that is more authentic and better aligned with some but not all of the students' needs? Even as I continue to struggle with these questions, I know that thanks to my partnership with Gwendolyn, I am growing into a more attuned educator with a more expansive understanding of students' learning and listening styles and preferences.

Gwendolyn: The partnership I had with Jerusha was without a doubt an eye-opening experience for me as a student, as I engaged with and learned much about what it means to be learning. As a student, I was made aware of how my preferred form of learning - both listening and being listened to in particular-strongly impacted the way that I observed her classroom. The past 19 years had trained me well in my role as a passive student, and I often caught myself slipping into that role rather than being the active observer I wanted to be. My instinct to sit, listen, and take notes on everything that Jerusha said heightened my awareness of both how other students were reacting to her and her activities and how she was saying what she was saying. 


\section{CONCLUSION}

While considerable research draws attention to the importance of building students' metacognitive habits and helping them to learn how they learn, it may not be as necessary for all students to recognize, let alone to overcome, their apprenticeships of observation, as it is for teachers. However, we have found that it can be useful for student partners to engage with this concept as they reflect on their experiences as learners, as it can provide a shared touchpoint for discussions and a way to connect the peer conversations all student partners have to oneon-one faculty feedback and debriefing sessions. When both the professor and the student partner can speak clearly about how their apprenticeship has shaped their perceptions of effective teaching and supportive learning environments, they can co-construct a framework within which to situate their shared and divergent perspectives on the work they are doing together to support deeper, transformative student learning. We have found that when this kind of sharing happens, the professor and student can be transformed as well.

\section{NOTES ON CONTRIBUTORS}

Jerusha Conner is an Associate Professor of Education at Villanova University. Her research focuses on youth organizing and activism, student voice in education policy, and student engagement.

Gwendolyn Vary is a history major at Bryn Mawr College, Class of 2017, with a concentration on gender and sexuality and a minor in educational studies.

\section{REFERENCES}

Cook-Sather, A., \& Abbot, S. (2016). Translating partnerships: How faculty student collaboration in explorations of teaching and learning can transform perceptions, terms, and selves. Teaching and Learning Inquiry, 4(2). Retrieved from http://tlijournal.com/tli/index.php/TLI/article/view/108

Cook-Sather, A., \& Motz-Storey, D. (2016). Viewing teaching and learning from a new angle: Student consultants' perspectives on classroom practice. College Teaching, 64(4), 168177.

Conner J. (2012). Steps in walking the talk: How working with a student consultant helped me integrate student voice more fully into my pedagogical planning and practice. Teaching and Learning Together in Higher Education, 1(6). Retrieved from http://repository.brynmawr.edu/tlthe/vol1/iss6/6/

Lortie, D. C. (1975). Schoolteacher: A sociological study. Chicago: University of Chicago Press. 